\title{
Application of Maslow's Hierarchy of Needs in a Historical Context: Case Studies of Four Prominent Figures
}

\author{
Aishwarya Shahrawat ${ }^{1}$, Renu Shahrawat ${ }^{2}$ \\ ${ }^{1}$ Department of Applied Psychology, University of Delhi (South Campus), New Delhi, India \\ ${ }^{2}$ Department of Reproductive Biomedicine, National Institute of Health and Family Welfare, New Delhi, India \\ Email: aishwarya.anime@gmail.com
}

How to cite this paper: Shahrawat, A., \& Shahrawat, R. (2017). Application of Maslow's Hierarchy of Needs in a Historical Context: Case Studies of Four Prominent Figures. Psychology, 8, 939-954. https://doi.org/10.4236/psych.2017.87061

Received: April 3, 2017

Accepted: May 13, 2017

Published: May 16, 2017

Copyright (c) 2017 by authors and Scientific Research Publishing Inc. This work is licensed under the Creative Commons Attribution International License (CC BY 4.0).

http://creativecommons.org/licenses/by/4.0/

\section{(c) (i) Open Access}

\begin{abstract}
Needs are all-pervasive. For Maslow, these were also innate. Being the basic drivers of behaviour, these have existed in an individual since time immemorial. This paper explores the application of Maslow's Hierarchy of Needs at the individual level through case studies of four prominent historical figures. Through this analysis, it was found that the personalities could be arranged along a continuum of human functioning. The individual personalities displayed varying needs ranging from self-actualization to signs of metapathology. This dynamicity of human behaviour towards different and varying ends can be a potential source of newer insights furthering the cause of human development and evolution.
\end{abstract}

\section{Keywords}

Maslow's Hierarchy of Needs, Humanistic Psychology, Metapathology

\section{Introduction}

In today's world of competition, deceit, conflict, war and chaos, the peace bird is seldom visible but nevertheless it still flies. Likewise, the spirit of humanism continues to thrive in the heart of many, albeit covertly. It is this side of the human nature that the Third Force of Psychology brought before us, way back in the 1960's through Maslow's Hierarchy of Needs. Graphically a pyramid, it represented a five-step staircase for human achievement (see Figure 1).

1) Physiological Needs: Represents the most basic, instinctoid needs vital for survival, such as the need for water, air, food, sex and sleep.

2) Security Needs: Comprises of needs for safety, security, stability, protection, order, and freedom from fear and anxiety. 


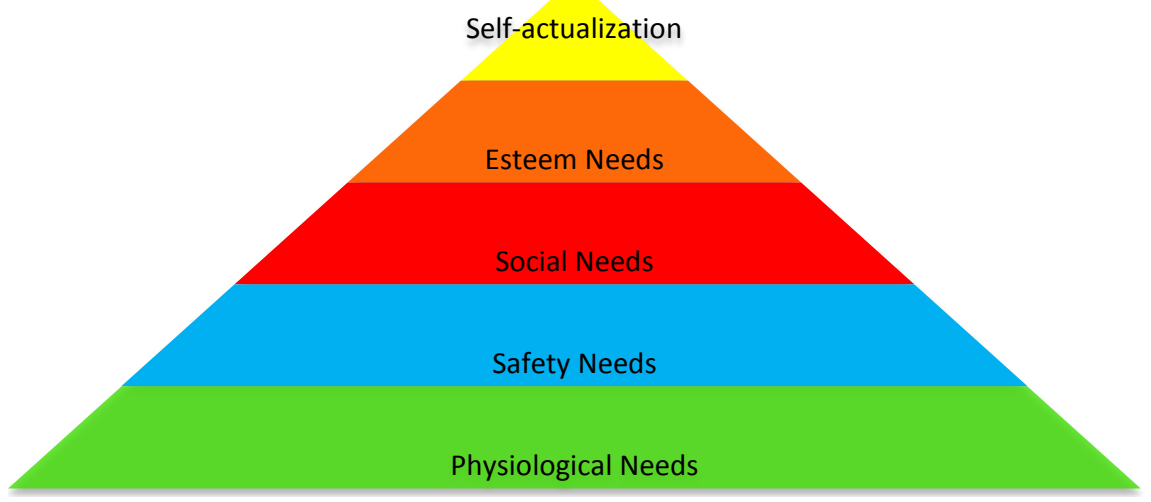

Figure 1. Maslow's hierarchy of needs.

3) Social Needs: Include the needs for belongingness, love and affection, mostly satisfied through involvement in personal relationships as well as through social, community or religious groups.

4) Esteem Needs: Primarily of two types: esteem derived from others and self-esteem. The former comprises of externally derived esteem based on reputation, admiration, status, fame, prestige, social success and all characteristics of how others think and react to people. Self-esteem, on the other hand, results from internal feelings of adequateness and worthiness based on the confidence and feelings of being secure inside, in a person.

5) Self-actualizing Needs: The highest level of Maslow's hierarchy, it essentially connotes "becoming all that one is capable of becoming" (Maslow, 1970). Such people tend to be self-aware, concerned with personal growth, less concerned with the opinions of others and interested in fulfilling their potential.

Maslow (1954) believed that these needs are inherent, innate and universal in nature. Also, for him, human beings are not motivated by all five needs at the same time. Rather only one need is paramount at any given moment. Lastly in the context of the hierarchy, only after fulfilling the lower-order needs (physiological, safety and social needs) can the individual move on to the higher-order needs (esteem and self-actualization).

Maslow further distinguished between the kinds of motivation experienced by the extremely healthy people (meta-motivation) as opposed to deficiency-motivation experienced by the others. In deficiency-motivation the person tries to make up for some deficiency (usually pertaining to the initial four needs described before) whereas meta-motivators work towards the goal of enriching and enlarging the experience of living, to increase the joy and ecstasy of being alive.

Likewise, for him, self-actualizers are motivated by meta-needs or Being-needs and others are by Deficiency-needs. Maslow set forth a list of meta-needs which seem to constitute states of growth or Being, towards which self-actualizers move. Frustration of the meta-needs produces metapathology. In contrast to deficit needs, the origin of metapathology is rather formless and one cannot attribute it to something concrete, like the feeling of hunger, as in the case of deficiency of physiological needs. For further clarity, the following example from 
Maslow's list is presented below:

B-value: Truth; Corresponding metapathology: Mistrust, Cynicism and skepticism.

Like any good theory, Maslow's Hierarchy has had its fair share of criticism and adulation. It has enjoyed popularity across circles (Gibson, Ivancevich, \& Donnelly, 1976) as it retained its intuitive appeal (Adler, 1977). Likewise, it generated a good heuristic impact (Taromina \& Gao, 2013; Wicker et al., 1993) venturing even into interdisciplinary domains (Kenrick, Griskevicius, Neuberg, \& Schaller, 2010; Trigg, 2004). On the other hand, the following limitations have acted as a major roadblock for its wide applicability. Questions have been raised regarding the hierarchal nature of the theory (Rauschenberger, Schmitz, \& Hunter, 1980); and its functioning (Sackett, 1998; Frame, 1996). Lack of empirical support (Wahba \& Bridwell, 1976; Deci, 1975; Berkowitz, 1969; Cofer \& Appley, 1964) has been a major stumbling block for its wide outreach. Moreover, the theory has remained silent on the importance of inner thoughts and feelings on satisfying various needs (Sengupta, 2011) while also ignoring the role of culture and learning (Neher, 1991).

Nevertheless, the theory has survived the test of time. Many research studies have described the applicability of Maslow's Hierarchy theory at varying levels, ranging from the macro to the micro. In the former category, the theory has been applied in the context of nations as a whole (Raymond, Mittelstaedt, \& Hopkins, 2003; Hagerty, 1999; Sirgy, 1986; Buera \& Glueck, 1979) and in the later at the level of organizations (Harell \& Daim, 2010; Amato \& Amato, 2002; Jeannet \& Hennessey, 1998; Wanous \& Zwany, 1977; Huizinga, 1970). Similarly, the theory has even been applied in non-work settings (Jamal, Baba, \& Mitchell, 1982) although there is more scope for exploration here. On the other extreme, it has been used to develop programs for school children (Yates, Saunders, \& Watkins, 1980), for the teachers (Deibert \& Walsh, 1981), to study the hierarchical need differences among gifted boys and girls (Groth \& Holbert, 1969).

In light of the above, the present study can be called a sui-generis. Accordingly, the idiosyncrasies, which make it stand out, are highlighted below:

Maslow (1970) offered the theory of Hierarchy of Needs as a theory of individual need development. In other words, while it has been applied across a wide variety of settings ranging from nations to specific groups, Maslow's focus on the individual as unit of analysis has seldom been explored. Additionally, there is hardly any research available assessing metapathology in the individual using Maslow's theory. A blockage in the natural process of satisfaction of growth needs is a precursor to metapathology. While the humanistic thought emphasizes the positive nature of human beings, however the other side to their being doesn't cease to exist. It is this side that Maslow covers in his domain of metapathology. Nonetheless, most have looked at Maslow's theory only from one angle i.e. the meta-needs and seldom exploring the other side. Borrowing from Maslow's emphasis on the individual the present study aims to examine the predominant need of an individual's life around which most of his/her beha- 
vioural actions were centered.

\section{Methods}

While it is important to apply the knowledge acquired over the centuries of human existence, one must also turn to the past to develop newer insights. Past is what lead us to the present and it definitely has the potential to pave the way for the future, for which merely an effort needs to be made. Likewise, this paper seeks to analyze the life of four historical personalities from Maslow's lens.

To study the application of Maslow's Hierarchy of Needs at the individual level, we chose four case studies of prominent historical figures who were connected in some way to the Indian subcontinent. Two of these i.e. Genghis khan and Mother Teresa were born in foreign countries where as the other two i.e. Ashoka and Aurangzeb were born in India. These personalities prominently figure in Indian history from ancient to modern times. These four figures were chosen keeping in mind the different characteristic acts each had demonstrated and their impact on the world. Mother Teresa and Genghis Khan represent the opposite poles on the continuum of humanity, while Ashoka and Aurangzeb fall somewhere in the middle. However, it is their individualistic responses to the life circumstances, which laid the foundation of how they are remembered today. The details about the life histories were taken from open sources available on the internet (Wikipedia).

While carrying out the analysis, their life as a whole was taken as the unit of study. Specific incidents, time periods and events weren't given undue importance except to make some necessary clarifications. A holistic view of their life formed the basis of inquiry using Maslow's Hierarchy of Needs. Their entire life was summarized in the form of a case-history to carry out the analysis. Their actions and behaviours throughout the life were examined. Consequently, their predominant need in life was identified.

Before moving on to the case studies and their analysis, it is important to clarify that nowhere, has it been claimed that the personalities did not experience any of the other needs ever. Here the effort has been directed to merely identifying the preponderance and predominance of a need in their life, which has been the driving force for their existence.

\section{Analysis}

\subsection{Case Study 1: Life History of Genghis Khan}

Genghis Khan was born in Mongolia around $1162 \mathrm{AD}$ and named "Temujin". When Temujin was 9 years old his father was deceptively killed while returning home after delivering Temujin to live with the family of his future bride, Borte. Upon returning home to claim his position as clan chief, the clan refused to recognize the young boy's leadership and ostracized his family to near-refugee status. The pressure on the family was great, and in a dispute over the spoils of a hunting expedition, Temujin killed his half-brother, confirming his position as head of the family. His mother taught him the grim reality of living in turbulent 
Mongol tribal society and the need for alliances. At 16, Temujin married Borte, cementing the alliance between her tribe and his own.

Around $1177 \mathrm{AD}$, Temujin was captured in a raid by former family allies, and temporarily enslaved. After escaping from there, Temujin began his slow ascent to power by building a large army of more than 20,000 men. He set out to destroy traditional divisions among the various tribes and united the Mongols under his rule. Through a combination of outstanding military tactics and merciless brutality, Temujin avenged his father's murder. Temujin's Mongols then defeated his former family allies using a series of massive cavalry attacks, and had all their chiefs boiled alive. Following the victories over the rival Mongol tribes, other tribal leaders agreed to peace and bestowed on Temujin the title of "Genghis Khan," which means "universal ruler". The title carried not only political importance, but also spiritual significance. Religious tolerance was practiced in the Mongol Empire, but to defy the Great Khan was equal to defying the will of God. The early success of the Mongol army owed much to the brilliant military tactics of Genghis Khan and his understanding of his enemies' motivations. He employed an extensive spy network and was quick to adopt new technologies from his enemies. The Mongol army was devastating in their attacks.

Initially, Genghis Khan used diplomacy to establish trade relations, however in case of deception or defiance, the result was disastrous. The Mongols swept through every city's fortifications with unstoppable savagery. Those who weren't immediately slaughtered were driven in front of the Mongol army, serving as human shields when the Mongols took the next city. No living thing was spared, including small domestic animals and livestock. Skulls of men, women, and children were piled in large, pyramidal mounds. City after city was brought to its knees, with the ruler and his heir(s) being captured and killed, bringing an end to the non-complying dynasty. Because of his large scale killings, like he killed three-fourth of population of the Iranian Plateau, he was also known as a genocidal ruler.

His massive empire was governed by a legal code known as Yassa. Developed by Genghis Khan, the code was based on the Mongol common law. On the other hand, advancement within military and government ranks was not based on traditional lines of heredity or ethnicity, but on merit. There were tax exemptions for religious and some professional leaders, as well as a degree of religious tolerance. Nevertheless, he forbade many cultural and religious practices of Jews and Muslims and forced Mongol ways of eating. In his life Genghis, experienced betrayals and conspiracies from many quarters including from former allies, his son Jochi and influential shamans.

Genghis Khan died in 1227. The exact reason of his death is uncertain. Besides conquering large parts of Eurasia, by the end of his life, his Empire included substantial portions of Central Asia and China.

\subsection{Analysis of Genghis Khan's Life History}

Genghis Khan has been seen as a savage crusader. His invasions and the result- 
ing wars are an example of the same. Some would call him "inhuman" considering his deeds and actions. Much opposed to Maslow's idea of an extremely healthy person, Genghis Khan symbolized just the other end. He believed in force and in use-and-throw of everything and anything that came in his path. For the people today, he epitomises the cruelest and demonic form, a human can possibly take. The heartless side of his functioning overpowered the subtle softness he portrayed in certain spheres of life. Having being allocated such titles as opposed to the ones given at his time, his analysis using Maslow's Hierarchy of Needs is rather very different than as Maslow would have liked or wanted.

Being born in a tribe where his father was the Chief and yet having to face the subsequent experiences of a difficult childhood made Genghis Khan a rather ruthless individual for whom gratification of his immediate needs was of utmost importance. One can speculate that he never moved beyond security and safety needs. Genghis Khan is known more as an attacker, a conqueror and in this process, his safety can be said to be of equal, rather utmost importance. Never being quoted as a good example of humanity, little is expected that he would have been truly loved and treasured by the people of his Empire, indigenous as well as conquered alike. Scarcity of facts to present the perspectives of the commoners leaves one with the only option of speculating. Except for maybe the soldiers of his army, with whom he would have interacted more than his own family members very few could be expected to have liked him as their Emperor.

However, never reaching the stage of self-actualization, his personality seems to display metapathologies. Frustration of the meta-needs, the metapthologies also represent a diminution or thwarting of full human growth and development. Their existence prevents one from fully expressing, utilizing and fulfilling one's potential. Genghis Khan displayed the following metapathologies: mistrust, hatred, black/white thinking, deadness, chaos, anger, insecurity, fatigue and senselessness of life. It can thus be stated that probably the presence of these metapathologies prevented Genghis Khan from realizing the higher potential, self-actualization.

\subsection{Case Study 2: Life History of the Mother Teresa}

Mother Teresa was born on August 27, 1910 in Macedonia. Mother Teresa's original name was Agnes Gonxha Bojaxhiu. Her father was a successful merchant and she was the youngest of the three siblings. She received her First Communion at the age of five and a half years. Her father's sudden death when she was about eight years old, left the family in financial straits. Her mother raised the children firmly and lovingly, greatly influencing her daughter's character and vocation. At the age of 12 , she decided that she wanted to be a missionary and spread the message of Christ. At the age of 18 years, she left her parental home in Macedonia and joined the Sisters of Loreto, an Irish community of nuns with missions in India. There she received the name Sister Mary Teresa.

After a few months of training at the Institute of the Blessed Virgin Mary in Dublin, Mother Teresa came to India in 1929. In 1937, Sister Teresa made her 
Final Profession of Vows, completely devoting herself to the path of Jesus for all eternity. From that time on she was called Mother Teresa. She continued teaching at St. Mary's and in 1944 became the school's principal. A person of profound prayer and deep love for her religious sisters and her students, Mother Teresa's twenty years in Loreto were filled with profound happiness. Noted for her charity, unselfishness and courage, her capacity for hard work and a natural talent for organization, she lived out her consecration to Jesus, in the midst of her companions, with fidelity and joy. In 1946, it is believed that during a train ride from Calcutta to Darjeeling for her annual retreat, Mother Teresa received her "inspiration," her "call within a call." On that day, in a way she would never explain, Jesus' thirst for love and for souls took hold of her heart and the desire to satiate His thirst became the driving force of her life. He apparently asked Mother Teresa to establish a religious community, Missionaries of Charity, dedicated to the service of the poorest of the poor. The primary task of the Missionaries of Charity was to take care of those persons whom nobody was prepared to look after. However, the prevailing poverty in Calcutta (present day Kolkata) had a deep impact on Mother Teresa's mind and in 1948, she received permission from her superiors to leave the convent school and devote herself to working among the poorest of the poor in the slums of Calcutta.

Providing a peek into her benevolent services, she visited families, washed the sores of some children, cared for an old man lying sick on the road and nursed a woman dying of hunger and TB. After some months, she was joined, one by one, by her former students. By the early 1960s, Mother Teresa began to send her Sisters to other parts of India. Eventually by the 1990's, Mother Teresa opened houses in almost all of the communist countries, including the former Soviet Union, Albania and Cuba. She received a number of awards and distinctions for her selfless service and humanitarian work.

Mother Teresa's life and labour bore witness to the joy of loving, the greatness and dignity of every human person, the value of little things done faithfully and with love. She died on September 5, 1997, just 9 days after her $87^{\text {th }}$ birthday. She was given the honour of a state funeral by the Government of India and her body was buried in the Mother House of the Missionaries of Charity. Her tomb quickly became a place of pilgrimage and prayer for people of all faiths, rich and poor alike. Mother Teresa left a testament of unshakable faith, invincible hope and extraordinary charity.

\subsection{Analysis of Mother Teresa's Life History}

It is often said that "The great people never die, their body gives up, but they continue to live in the hearts of their followers". Mother Teresa embodies one such personality whose language of love touched and connected a million hearts across the barriers of region, language and religion.

Mother Teresa can be said to represent Maslow's concept of the extremely healthy individual. In terms of Maslow's Hierarchy of Needs, Mother Teresa can be said to have reached the stage of self-actualization. Mother Teresa's work and 
outlook on life reflect that she was metamotivated-a person beyond striving, desiring, or wishing for something in order to correct a deficit. Her life displays the following meta-needs: goodness, unity, dichotomy transcendence, aliveness, uniqueness, simplicity and self-sufficiency. In addition, Mother Teresa's personality shows the following characteristics of a self-actualized person: a general acceptance of nature, others and oneself; spontaneity, simplicity and naturalness; a focus on problems outside themselves; autonomous functioning; a continued freshness of appreciation; mystical or "peak" experiences; social interest; intense and stronger interpersonal relations; a democratic character structure and resistance to enculturation.

At the same time, it can be contested that she also operated at the level of the social needs of love, belongingness and affection. While she undoubtedly displayed these in her life pervadingly however, when compared to self-actualization, the latter wins the case. The reason behind this is that, as she helped and served people while spreading the message of the power of human touch, she did not do so for her own personal goals but for the larger good. The intention behind her actions, it can be speculated, was not to get adulation and love from others, but to fulfill the desires of Jesus, to whom she had completely devoted her life and whose cause she sought to address. The selfless nature of her gives her place on a higher pedestal compared to someone ordinarily operating on the level of the social needs.

Mother Teresa can be said to have been one of the best examples of humanity. She has adequately supported the humanistic view that "human beings possess more potential than they realize". Her teachings continue to live on, and with her heart-warming message to humanity of kindness and selfless service, she has very rightly been bestowed the title of "An Enlightened Soul".

\subsection{Case Study 3: Life History of Aurangzeb}

Abul Muzaffar Muhy-ud-Din Muhammad Aurangzeb Alamgir (1618-1707) more commonly known as Aurangzeb or by his chosen imperial title Alamgir, an urdu word meaning "Conqueror of the World", was born the third son and sixth child of Prince Khurram (later Shah Jahan) and Mumtaz Mahal. As a child, Aurangzeb had a keen mind and quickly learnt what he read. He mastered the Quran and readily quoted from it. He received formal education in Arabic and Persian. He was a strict follower of Sufism. Enthused by the study of history, he spent his daily allowances on it as well as in religious education.

At 15 years of age, he narrowly escaped death in an elephant fight and successfully defended himself from a stampede (for which he was bestowed the title of "Bahadur" by his father). In 1636, he was made the Viceroy of the Deccan. He stayed there for a considerable time, carrying out the duties assigned to him. Meanwhile Shah Jahan, the ruling Mughal Emperor in Agra began favouring his elder son Dara Shikoh in the court. As fate had planned it, in 1644 due to an unfortunate accident his sister Jahanara got burnt and as a result of his late arrival in the Agra fort to meet his sister (that too in fully armoured war attire) angered 
the Emperor. As a consequence, he was stripped off his prestigious post. After years of struggle on the field, he was reappointed as the Viceroy of the Deccan. Subsequently, he led bloody battles that led to the expansion of the Mughal Empire. Differences of opinion between the father and the son, on a variety of issues, further widened the chasm.

Shah Jahan fell ill in 1657 and placed his favourite son, Dara Shikoh, as his successor. This angered Aurangzeb who fought a bloody battle against his brother. This war of succession ended in the imprisonment of his father and the ruthless killing of Dara Shikoh. It is believed that he sent the severed head of Dara Shikoh to his father as a present to display his might and power.

As the new Emperor he introduced a variety of changes in his kingdom: On the one hand he authorized the Fatawa-e-Alamgiri (a compilation of law) over the entire Empire, briefly taxed non-Muslims, destroyed many Hindu temples which were accused of syncretism and executed Guru Tegh Bahadur (because he objected to Aurangzeb's forced conversions). On the other hand he increased the number of Hindu administrators and senior court officials and many Hindu and Sikh temples continued to expand during his reign, depending mainly upon the situational factors.

As can be adjudged, he was constantly at the field fighting wars either to expand his Empire but mostly to deal with rebellions taking place under his rule. Aurangzeb died at the age of 88 years in Ahmednagar. On his deathbed, it is believed that he acknowledged his mistakes and asked his successors to seek inspiration from the liberal policies of his predecessors, and not from his.

\subsection{Analysis of Aurangzeb's Life History}

In view of the extensive knowledge present concerning Aurangzeb's life, the analysis below is enmeshed with other facts not presented above.

Aurangzeb has been viewed widely as the most ruthless Mughal Emperor in the history of India. However, an individual is never born ruthless and even the cruelest of the cruel have had some soft sides to them. Aurangzeb is no exception.

Although little is known about his personal life, it is believed that he used to stitch caps (used during prayers in mosques even today) and wrote the Holy book Quran to earn his personal allowance as he did not use the royal treasury for personal expenses or extravagant building projects. Aurangzeb under the umbrella of religion, tried to foster good values and moralistic standards among his people by banning the consumption, usage and practices of alcoholism, gambling, prostitution, castration and servitude among many others.

After having had a look at the positive side of his personality, alongside his life history, one can now present an analysis of Aurangzeb's personality in relation to Maslow's Hierarchy of Needs. Aurangzeb being born a prince and later having ruled the largest Mughal Empire, can be speculated to have all his physiological needs met well. Although having faced grave dangers to his life from early on (15 years of age), he did manage to live a long life of 88 years, thus out-living 
many of his children. Being a royal holding various important positions in his life (e.g. the Emperor of Mughal empire), It can be hypothesized that he must have ensured great amount of security and protection around him. Thus, it could be stated that his safety needs were also covered. Although the question of stability could be raised (as could be seen from the various rebellions he faced), however concerning how the events folded during his lifetime, these can be claimed to be more situational and peppered. Nevertheless, these did influence his functioning and did play a decisive role in the actions he would undertake.

Next in the hierarchy come the social needs of belongingness, love and affection. Despite having good relations with his father early on, the events preceding the war of succession alienated him from his family members, resulting in the destruction of the familial bonds. However, being a devout follower of religious laws and practices, earned him a lot of praise from the Sufi saints and other strict followers of Sunni Islam. Opposition of the Emperor was a taboo and thus, among his immediate contemporaries, it can once again be speculated that he was looked after and cared for. Apart from this, he did not share a good rapport with his children, some of whom opposed his rule and ended up getting killed, while others faded into non-existence. One doesn't know if questions of love, family, personal brotherhood crossed his mind as his thirst for power and autonomy is believed to be higher. At an overall level, one can possibly say that he lacked social needs.

Aurangzeb's life, particularly the later half was dominated by wars, mostly resulting from opposition from people, based on various issues. These rebellious wars do spell the fact that Aurangzeb's life was constantly in danger. Also being the most dreaded and feared ruler of the time, he was always perceived in negative light, being associated with death and destruction. Drawing from the above, one can speculate that Aurangazeb's safety, social and esteem needs were simultaneously being attacked. Furthermore, it can be stated that he was motivated by deficiency needs -constantly trying to fulfil the needs for safety, love, belonging and esteem as well. In addition, it can be possibly said that Aurangzeb's attempts to overcome each of these, while not completely satisfying even one in the process, might have stopped him from achieving the stage of fullest human potential, self-actualization.

However the realization of his acts and deeds came to Aurangzeb pretty late in his lifetime (on his deathbed). Had he been more sensitive towards his doings earlier on in life, it is quite possible that he would have turned out to be a very different personality than is popularly known. It is difficult to imagine but $\mathrm{Au}$ rangzeb could have turned out to be an enlightened soul as he did have the potential in him (an intelligent person who was able to master the Quran at a young age!).

\subsection{Case Study 4: Life History of Ashoka}

Ashoka (Asoka) was the third ruler of the Mauryan Empire. Little information is available about his childhood. He was Bindusara's son, though not the eldest. In- 
itially, it is believed that he was an exceptionally cruel and ruthless prince, who had many of his brothers killed in order to seize the throne. His prime importance thereafter had been to expand the boundaries of his Empire and for the same continued on his journey southwards. This frightening and heartless warrior's bloodthirstiness was quenched in the barbaric war of Kalinga (261 BCE), which surprisingly instilled in him the feelings of remorse and the meaninglessness of war. It is believed to have been so devastating that the river near the battle-ground was filled with blood of men from both sides. The resulting impact on Ashoka saw the greatest of the Mauryan rulers converting to Buddhism (from Vedic Hinduism) and renouncing war as an instrument of policy and thereon ruling justly and wisely.

Changes observed in Ashoka, post-war were: he became vegetarian, prohibited the killing of some animals, discouraged hunting, instead urging people to go on pilgrimages. He also built many shrines in places associated with the Buddha's life. He honoured all religions and holy men. The judicial system was reformed in order to make it fairer, less harsh and less open to abuse, while those sentenced to death were given a stay of execution to prepare appeals and regular amenities were given to prisoners. State resources were used for useful public works. He also exhorted his people to practice virtue, be honest, obey their parents, and be generous to servants. He forbade some amusements as immoral and appointed morality officers to enforce proper conduct among officials and the people. He encouraged generosity to the poor, to ascetics and Brahmins, and to friends and relatives. Ashoka encouraged harmlessness towards all living beings, performing ceremonies that were supposed to bring good luck. Because it helped promote tolerance and mutual respect, Ashoka desired that people should be well-learned in the good doctrines of other people's religions. Moreover, Ashoka called the people of the Empire his children and sought to nurture and protect them as a father would.

A great deal is known about the policy of Ashoka because he ordered many of his edicts, laws, and pronouncements engraved on stone pillars and rock surfaces throughout his Empire and ordered his officials to read them to the public periodically as instructions. Likewise, speculations about his personality too have been construed from these. Ashoka's edicts were written in a style that tends to be somewhat repetitive and plodding, as if explaining something to one who has difficulty in understanding. Ashoka frequently refers to the good works he has done, although not in a boastful way, but more, it seems, to convince the reader of his sincerity. Ashoka emerges from his edicts as an able administrator, an intelligent human being and as a devoted Buddhist. The qualities of the heart that are recommended by Ashoka in the edicts indicate his deep spirituality. They include kindness, self-examination, truthfulness, gratitude, purity of heart, enthusiasm, strong loyalty, self-control and love for the dharma.

He died in 232 BCE. Little is known of his last years. It is also unclear who succeeded him. History honours Ashoka as a remarkable man and great king. Present-day India has his lion and the wheel of Buddha's law (The Dharamcha- 
kra) inscribed on a pillar that adorned his capital, as important symbols of the nation.

\subsection{Analysis of Ashoka's Life History}

It is often stated that "Birds of a feather flock together". After having covered Aurangzeb, one can't help but notice the similarities in the initial part of the lives of India's two mightiest rulers, Ashoka and Aurangzeb. However the later path of their respective lives throws the two rulers apart, leaving not even a single thread connecting them. A similar scene emerges when one begins to analyze the life of Ashoka.

Ashoka's life history is rather fascinating. It shows his transition from a cruel, ruthless king to a peaceful ruler fostering care and love for the humanity. This has also helped Ashoka to move up the ladder in terms of Maslow's Hierarchy of Needs. Ashoka as a ruler can be expected to have his basic physiological and safety needs well satisfied. Although he too fought wars but these weren't driven by as much a sense of protection as they were by the desire for conquest and expansion. The latter overtakes the former in primacy. Later on in life, he definitely seem to have surpassed and adequately satisfied his safety needs. Furthermore, being a just and caring ruler, it can be speculated that he was greatly valued and loved in his kingdom. Under his long rule, the Empire that he inherited reached its zenith territorially and culturally. His kind-heartedness and generosity are depicted in the edicts established by him. His any-time-availability to the people of his kingdom can be expected to have made him a highly revered king and the resultant feelings of affection and belongingness might have satisfied his social needs. Ashoka's esteem needs can be speculated to have been adequately fulfilled, considering his reputation, status and prestige at that time (his power and influence on the people of his time still remains one of the biggest examples in the history of India). His renunciation of war and adoption of a peaceful path to the life's journey, fostering the same amongst his people could be speculated to have brought internal satisfaction to him, thereby moving him up the ladder towards self-actualization.

Ashoka did display some of the characteristics of a self-actualized person. $\mathrm{He}$ was thoughtful and considerate of others, had a sense of dedication in his work(as can be inferred from his instructions to the officials to periodically repeat the laws and edicts engraved on the stone pillars), possessed strong and deep feelings of empathy and affection for all human beings, a desire to help humanity, fostered greater love, deeper friendship among his people, was tolerant and treated everyone equally, and was inventive and innovative in his approach to people(making himself all-time accessible). In addition to this, one can possibly say that he was motivated by meta-needs as he possessed the following B-values: goodness, unity, uniqueness (was nothing like his predecessors), justice and order. Thus it can be affirmatively stated that Ashoka was in the process of self-actualizing, trying to become all that he could. 
It can't be explicitly stated whether Ashoka was a self-actualized person or not. A lack of insights into his feelings and thoughts about ruling his kingdom post the transformation restricts us to fully comprehend his position on the Maslow's ladder. If he acted out of remorse post the Kalinga war, then probably more than a self-actualized individual, he worked on the level of social and esteem needs. However, one can say more affirmatively that in the absence of the deadly war of Kalinga and the subsequent realization that dawned upon him, Ashoka could not have reached the place in history where he stands today.

\section{Discussion}

The findings of this paper can be said to represent a continuum of human functioning. At the one end lies Mother Teresa, the epitome of human grace, symbolizing the self-actualized person. On the other end of the spectrum stands Genghis Khan, a person displaying signs of metapathology, the complete opposite of a person satisfying the meta-needs. Along this path, lie the other two figures. While Ashoka moved towards the path of self-actualization, Aurangzeb continued to struggle to have his safety and social needs adequately met.

Some have argued that the need hierarchy may unfold over a lifetime (Wahba \& Bridwell, 1976; Deci, 1975). Following their lead, this paper sought to study the dominant needs at which the above four historical personalities functioned in terms of Maslow's Hierarchy. Moreover, Maslow (1954) propounded the concept of "holism" wherein he believed that the system of needs must be studied as a whole rather than as individual needs independently. Likewise, this paper sought to evaluate the need hierarchy of the four prominent figures holistically and not necessarily independently. An exception to this was noted in the last two cases of Aurangzeb and Ashoka, wherein there was an apparent neck-toneck comparison. This view has been corroborated by McGregor (1960). According to McGregor, the dominant motivators in an individual represent those emerging needs that direct the individual's behaviour towards their fulfillment. Similarly, the continuous efforts of a person's life provide an indication of the level/need at which s/he operates, in terms of Maslow's Hierarchy. Additionally two major limitations of Maslow's theory were encountered during the analysis. In all the cases, the predominance of one paramount need was not necessarily found, on which the individual's life was probably centered around. Also an interplay between needs was noticed which could be said to dictate the individual's behaviour across his/her life.

Based on the afore-mentioned analysis, the dominant needs prevalent in each of the four personalities were identified and adequately highlighted. Maslow sought his theory to be analyzed form the point of view of the individual being the unit of analysis. This idiosyncratic focus has been largely overlooked as mostly research has sought to apply it on a large spectrum of settings namely, nations, schools, teachers, organizations (Harell \& Daim, 2010; Raymond, Mittelstaedt \& Hopkins, 2003; Amato \& Amato, 2002; Jeannet \& Hennessey, 1998; Sirgy, 1986; Deibert \& Walsh, 1981; Yates, Saunders \& Watkins, 1980; Buera \& 
Glueck, 1979). Due to lack of empirical support, the obtained findings can't be corroborated further. The exception being the case of Mother Teresa wherein some empirical backup is available. According to Sengupta (2011), higher needs may occasionally emerge not after the gratification of lower ones, but through discipline, asceticism or suppression. The case of the global mother, Mother Teresa, fits the bill perfectly here as her ascetic life displayed.

A cross-comparison of the four personalities yields the following interesting findings. While Mother Teresa and Genghis Khan can be visualized as two opposites at the end of the human spectrum, Aurangzeb and Ashoka represent the subtle differences that make one stand at a higher pedestal vis-à-vis the other. Generally a comparison across the life circumstances can't be drawn as they lived in different time periods which were highly distinct from each other. Nevertheless, the close similarity in the paths of Aurangzeb and Ashoka is unmistakable. While the former represents an emperor who waged battles till his last breath, the latter represented a king who renounced the path of war post a hard-won victory. Remorse was felt in the both their cases however Ashoka acted upon it well in time to cause a turn-around in his life, thereby elevating himself on the Hierarchy of Needs, while Aurangzeb could only lament during his last hours. An individual's actions can either make him or break him, a learning that can be found reverberating across all the above case studies.

In terms of the limitations encountered, the authors faced difficulty in both assembling the facts where they were too many and a problem of fact-crunch where there weren't any and they were left wanting for more. Also reliance on secondary data, especially in the case of historical facts, is always limited by the perspective from which it is written. There are differing angles from which a thing can be viewed however in the case of historical figures, the biggest disadvantage is that the voice of the other, the lower and the subjugated is seldom heard off. Therefore, a $360^{\circ}$ view of a person's life is not available to arrive at a more "realistic" understanding. Another hindrance encountered was while surmising the findings to objectively state that a person operated at a particular lev$\mathrm{el}$, is a luxury that only some can afford given the lack of insights into the feelings, thoughts and intentions of the individual. Nevertheless, looking at life from a new lens can provide useful insights for future development and also provide important lessons to further improve upon the existing knowledge. Following in Maslow's footsteps and taking a cue from his teachings, the growth process continues till the last breath.

\section{Conclusion}

This individualistic examination of Maslow's Hierarchy allows us to explore the dynamicity across human behaviour towards different and varying ends. These range from fulfillment of basic needs to achieving the ultimate stage of self-actualization. Focusing on the individual can yield insightful knowledge that may help to further the cause of human development by learning from the example of others. 


\section{References}

Adler, S. (1977). Maslow's Need Hierarchy and the Adjustment of Immigrants. The International Migration Review, 11, 444-451. https://doi.org/10.2307/2545398

Amato, C. H., \& Amato, L. H. (2002). Corporate Commitment to Quality of Life: Evidence from Company Mission Statements. Journal of Marketing Theory and Practice, 10, 69-87. https://doi.org/10.1080/10696679.2002.11501927

Berkowitz, L. (1969). Social Motivation. In G. Lindzey, \& E. Aronson (Eds.), Handbook of Social Psychology (pp. 50-135). Reading, MA: Addison-Wesley.

Buera, A., \& Glueck, W. F. (1979). The Need Satisfaction of Managers in Libya. Management International Review, 19, 113-121.

Cofer, C. N., \& Appley, M. H. (1964). Motivation: Theory and Research. New York: Wiley.

Deci, E. L. (1975). Intrinsic Motivation. New York: Plenum. https://doi.org/10.1007/978-1-4613-4446-9

Deibert, J. P., \& Walsh, K. J. (1981). Maslow and Team Organization. The Clearing House, 55, 169-170. https://doi.org/10.1080/00098655.1981.11478110

Frame, D. (1996). Malsow's Hierarchy of Needs Revisited. Interchange, 27, 13-22. https://doi.org/10.1007/BF01807482

Gibson, J. L., Ivancevich, J. M., \& Donnelly, J. H. (1976). Readings in Organizations: Behavior, Structure, Processes. Dallas, TX: Business Publications.

Groth, N. J., \& Holbert, P. (1969). Hierarchial Needs of Gifted Boys and Girls in the Affective Domain. Gifted Child Quarterly, 13, 129-133.

Hagerty, M. R. (1999). Testing Maslow’s Hierarchy of Needs: National Quality-of-Life across Time. Social Indicators Research, 46, 249-271.

https://doi.org/10.1023/A:1006921107298

Harell, G., \& Daim, T. U. (2010). HDM Modeling as a Tool to Assist Management with Employee Motivation: The Case of Silicon Forest. Engineering Management Journal, 22, 23-33. https://doi.org/10.1080/10429247.2010.11431850

Huizinga, G. (1970). Maslow's Need Hierarchy in the Work Situation. Groinger: Wolters.

Jamal, M., Baba, V. V., \& Mitchell V. F. (1982). The Nature of Need Structure in Nonwork. Relations Industrielles, 37, 618-633. https://doi.org/10.7202/029282ar

Jeannet, J.-P., \& Hennessey, D. H (1998). Global Marketing Strategies. Boston, MA: Houghton Mifflin.

Kenrick, D. T., Griskevicius, V., Neuberg, S. L., \& Schaller, M. (2010). Renovating the Pyramid of Needs: Contemporary Extensions Built Upon Ancient Foundations. Perspectives on Psychological Science, 5, 292-314. https://doi.org/10.1177/1745691610369469

Maslow, A. (1954). Motivation and Personality. New York: Harper.

Maslow, A. H. (1970). Motivation and Personality (2nd ed.). New York: Harper \& Row.

McGregor, D. (1960). The Human Side of Enterprise. New York: McGraw-Hill.

Neher, A. (1991). Maslow's Theory of Motivation: A Critique. Journal of Humanistic Psychology, 31, 89-112. https://doi.org/10.1177/0022167891313010

Rauschenberger, J., Schmitz, N., \& Hunter, J. E. (1980). A Test of the Need Hierarchy Concept by a Markov Model of Change in Need Strength. Administrative Science Quarterly, 25, 654-670. https://doi.org/10.2307/2392286

Raymond, M. A., Mittelstaedt, J. D., \& Hopkins, C. D. (2003). When Is a Hierarchy Not a Hierarchy? Factors Associated with Different Perceptions of Needs, with Implications for Standardization-Adaptation Decisions in Korea. Journal of Marketing Theory and 
Practice, 11, 12-25. https://doi.org/10.1080/10696679.2003.11658505

Sackett, S. J. (1998). Career Counseling as an Aid to Self-Actualization. Journal of Career Development, 24, 235-244. https://doi.org/10.1177/089484539802400306

Sengupta, S. S. (2011). Growth in Human Motivation: Beyond Maslow. Indian Journal of Industrial Relations, 47, 102-116.

Sirgy, M. J. (1986). A Quality-of-Life Theory Derived from Maslow's Developmental Perspective. The American Journal of Economics and Sociology, 45, 329-342. https://doi.org/10.1111/j.1536-7150.1986.tb02394.x

Taromina, R. J., \& Gao, J. H. (2013). Maslow and the Motivation Hierarchy: Measuring Satisfaction of the Needs. The American Journal of Psychology, 126, 155-177. https://doi.org/10.5406/amerjpsyc.126.2.0155

Trigg, A. B. (2004). Deriving the Engel Curve: Pierre Bourdieu and the Social Critique of Maslow's Hierarchy of Needs. Review of Social Economy, 62, 393-406. https://doi.org/10.1080/0034676042000253987

Wahba, M. A., \& Bridwell, L. G. (1976). Maslow Reconsidered: A Review of Research on the Need Hierarchy Theory. Organizational Behavior and Human Performance, 15, 212-240.

Wanous, J. P., \& Zwany, A. (1977). A Cross-Sectional Test of Need Hierarchy Theory. Organizational Behavior and Human Performance, 18, 78-97.

Wicker, F. W., Brown, G., Wiehe, J. A., Hagen, A. S., \& Reed, J. L. (1993). On Reconsidering Maslow: An Examination of the Deprivation/Domination Proposition. Journal of Research in Personality, 27, 118-133.

Wikipedia. https://en.wikipedia.org/wiki/Wikipedia

Yates, M. R., Saunders, R., \&Watkins, J. F. (1980). A Program Based on Maslow's Hierarchy Helps Students in Trouble. The Phi Delta Kappan, 61, 712-713.

Submit or recommend next manuscript to SCIRP and we will provide best service for you:

Accepting pre-submission inquiries through Email, Facebook, LinkedIn, Twitter, etc. A wide selection of journals (inclusive of 9 subjects, more than 200 journals)

Providing 24-hour high-quality service

User-friendly online submission system

Fair and swift peer-review system

Efficient typesetting and proofreading procedure

Display of the result of downloads and visits, as well as the number of cited articles

Maximum dissemination of your research work

Submit your manuscript at: http://papersubmission.scirp.org/

Or contact psych@scirp.org 